\title{
H.I. Насікан,
}

к.е.н., доцент кафедри менеджменту і маркетингу,

Київський національний лінгвістичний університет

ORCID ID: 0000-0001-6990-8584

Ю. С. Гриниук,

д.е.н., професор кафедри менеджменту, Білочерківсъкий начіональний аграрний університет

ORCID ID: 0000-0003-0297-7432

О.Г.Вдовічена,

к.е.н., доцент кафедри маркетингу циффрової економіки та підприємництва,

Чернівецький торговельно-економічний інститут

Київського начіонального торговельно-економічного університету

ORCID ID: 0000-0003-0768-5519

DOI: 10.32702/2306-6806.2021.3.71

\section{РИЗИК-ОРІСНТОВНИЙ МЕНЕАЖМЕНТ КОРПОРАТИВНИХ ПІАПРИЕМСТВ У СУЧАСНИХ УМОВАХ}

\author{
N. Nasikan, \\ PhD in Economics, Associate Professor of the Department of Management and marketing, \\ Kiev National Linguistic University \\ Y. Grynchuk, \\ Doctor of Economic Sciences, Associate Professor of the Department of Management, \\ Bila Tserkva National Agrarian University \\ O. Vdovichena, \\ PhD in Economics, Associate Professor of the Department of Commodity Studies, Marketing, Digital Economy \\ and Entrepreneurship, Chernivtsi Trade and Economic Institute of Kyiv National Trade and Economic University
}

\section{RISK-ORIENTED MANAGEMENT OF CORPORATE ENTERPRISES IN MODERN CONDITIONS}

У Сучасному світі господарюючі підприемства функціонують в Умовах невизначеності та Схильні до низки ендогенних й екзогенних ризиків, а успішність їньої діяльності залежить від організації цілісної системи управлінню ризиками. Це зумовлює необхідність формування в пі,дприємстві Системи ризик-орієнтовного менеджменту, тому метою статті є визначення особливостей реалізації ризик-менеджменту корпоративних підприємств. Устатті використано такі наукові методи: аксіоматичний, графічний, системного підходу та узагальнення. Встановлено внутрішні та зовнішні ризики діяльності корпоративних підприемСтв, у тому числі й Специфічні ризики, притаманні для корпоративної форми організації, зокрема: ризик "розмивання" частки акціонерів у Статутному капіталі, конфлікту інтересів; банкрутства; обгрунтованого трансфертного ціноутворення; реорганізації підприємства та виходу акціонерів із СкАаду Стейкходдерів; зміни корпоративної структури компанії (незавершеність консолідації холдингів); відсутності представників міноритарних акціонерів у СкАаді ради директорів; ризик, пов'язаний з участю корпоративних підприемствах, держави як акціонера. Окреслено особливості системи ризик-менеджменту підприємств, націленої на забезпечення стійкості та конкурентоспроможності корпоративного підприємства в мінливих економічних умовах. Запропоновано схему формування ризик-орієнтовного менеджменту корпоративних підприємств, яка передбачає управління ризиками на основі процесу їх ідентифікації, оцінки та аналізу, а також вибору і використання методів нейтралізації наслідків ризиків $з$ метою забезпечення стабільності та конкурентоспроможності підприємства. Визначено, що ризик-менеджмент має Стати невід 'ємною СкАадовою частиною загальної Системи уПравАіння діяльністю корпоратив- 


\section{ЕКОНОМІЧНА НАУКА}

ного підприємства, що реалізуеться 3 дотриманням принципів Структурованості та повноти менеАжменту, Системності, економічної обгрунтованості, адаптованість, до зовнішнього та внутрішнього середовища, Аинамічності, актуальності та оперативності, постійного моніторингу й удосконалення. Крім того, наголошено, що в основі ризик-орієнтовного менеджменту корпоративних підприемств лежить індивідуальний підхіА, аАже Аля кожної організації залежно віА виду діяльності, фінансової стійкості, участі акціонерів в управлінні, ринкової кон'юнктури та інших внутрішніх і зовнішніх чинників ризики с різними за характером та силою вПливу.

In today's world, businesses operate under uncertainty and are subject to a number of endogenous and exogenous risks, and the success of their activities depends on the organization of a holistic risk management system. This necessitates the formation of a system of risk-oriented management in the enterprise, so the purpose of the article is to determine the features of the implementation of risk management of corporate enterprises. The following scientific methods are used in the article: axiomatic, graphical, system approach and generalization. The internal and external risks of corporate enterprises, including specific risks inherent in the corporate form of organization, in particular: the risk of "erosion" of the share of shareholders in the authorized capital, conflict of in terest; bankruptcy; reasonable transfer pricing; reorganization of the enterprise and withdrawal of shareholders from stakeholders; changes in the corporate structure of the company (incomplete consolidation of holdings); absence of representatives of minority shareholders in the board of directors; risk associated with the participation of corporate enterprises of the state as a shareholder. The peculiarities of the risk management system of enterprises aimed at ensuring the stability and competitiveness of a corporate enterprise in changing economic conditions are outlined. The scheme of formation of risk-oriented management of corporate enterprises is offered, which provides risk management on the basis of the process of their identification, assessment and analysis, as well as selection and use of risk neutralization methods to ensure stability and competitiveness of the enterprise. It is determined that risk management should become an integral part of the overall management system of a corporate enterprise, implemented in compliance with the principles of structure and completeness of management, system, economic feasibility, adaptability to external and internal environment, dynamism, relevance and efficiency, constant monitoring. and improvement. In addition, it is emphasized that the risk-oriented management of corporate enterprises is an individual approach, because for each organization depending on the type of activity, financial stability, shareholder participation in management, market conditions and other internal and external factors, the risks are different and the force of influence.

Ключові слова: ризик-орієнтовний менеджмент, корпоративні підприємства, ризики діяльності, стратегія менеджменту.

Key words: risk-oriented management, corporate enterprises, business risks, management strategy.

\section{ПОСТАНОВКА ПРОБЛЕМИ}

Сучасні умови господарювання характеризуються динамічно мінливим зовнішнім середовищем, посиленням глобалізації, появою нових ринків, ускладненням і появою нових передових технологій, зміною споживчої поведінки та соціальних запитів суспільства, тому вимагають від підприємств оперативного виявлення та управління ризиками. Впровадження системи ризик-менеджменту сприяє досягненню підприємствами стратегічних і операційних цілей, а також високої ефективності господарської діяльності в умовах постійної невизначеності бізнес-середовища. Оскільки нині переважна частина діючих в Україні великих підприємств мають корпоративну організаційну форму, важливо розглянути особливості системи ризикорієнтованого менеджменту корпоративних підприємств у сучасних умовах господарювання.

\section{АНАЛІЗ ОСТАННІХ ДОСЛІДЖЕНЬ}

\section{ТА ПУБЛІКАЦІЙ}

Аослідження теоретичних і практичних питань проблематики ризик-менеджменту на підприємстві здійснювали багато вчених, серед них: B.I. Антоненко [2], К.В. Балдин [5], Т.А. Берегова [10], І.Г. Волинець [11], О.М.Аовганець [9], А.В. Аячков [8], Ю.М. Кривець [13], Т.А. Ковернега [4], Г.І. Коломієць [3], Н.В. Корж [12] та інші, праці яких присвячені аналізу окремих аспектів сутності ризиків, визначенню факторів і причин їх виникнення та управління. Проте необхідно зазначити, що існуючі підходи щодо вирішення проблемних аспектів ризик-орієнтовного менеджменту корпоративних підприємств є недостатньо висвітленими у наукових працях, тому потребують детальнішого вивчення. 


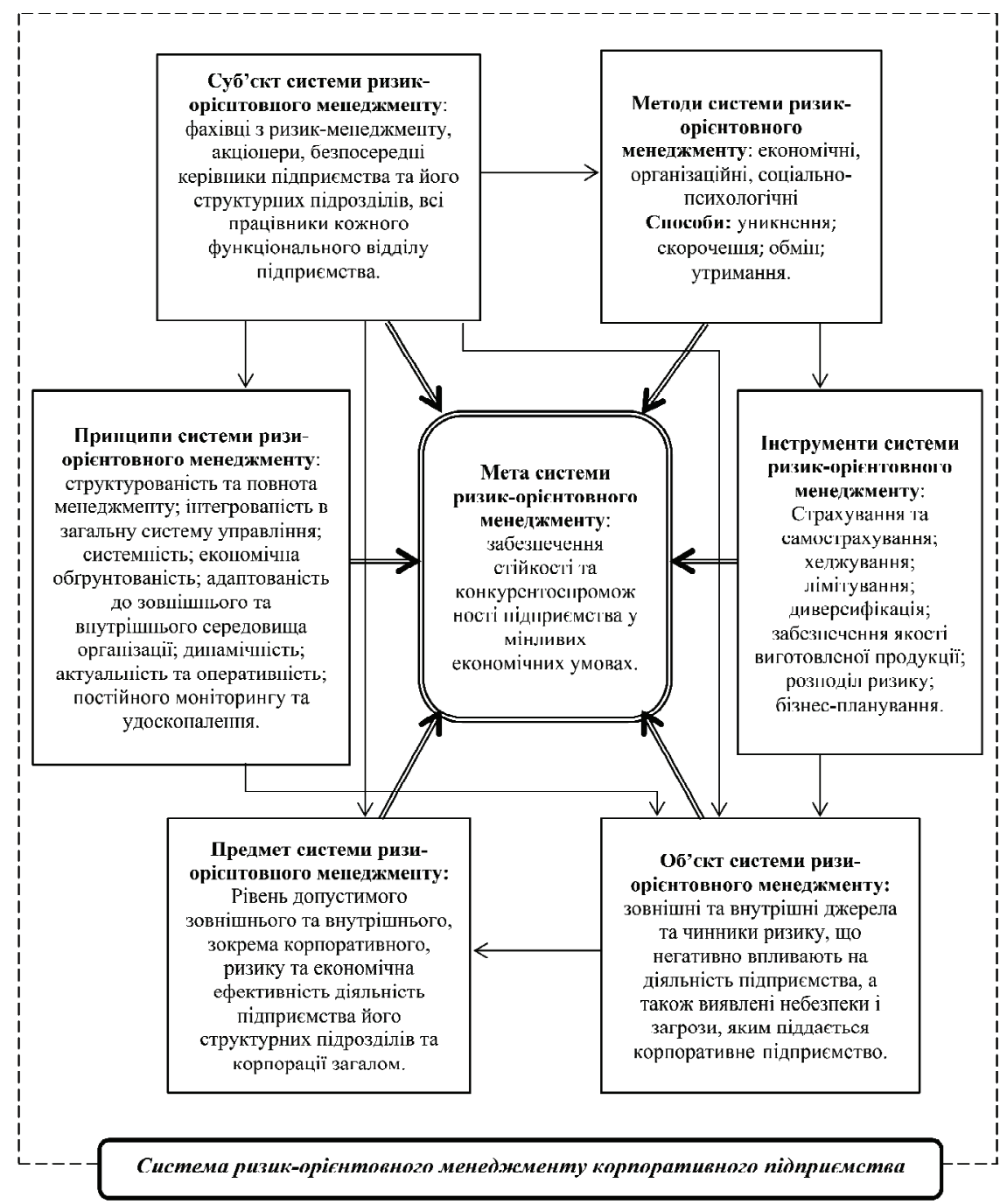

Рис. 1. Система ризик-орієнтовного менеджменту корпоративних підприємств

Ажерело: складено авторами.

\section{META CTATTI}

Метою статті є визначення особливостей системи ризик-орієнтовного менеджменту корпоративних підприємств у сучасних економічних умовах.

\section{ВИКЛАД ОСНОВНОГО МАТЕРІАЛУ}

Нині тенденцією розвитку вітчизняної економіки є формування великої кількості корпоративних підприємницьких утворень, які функціонують переважно у формі акціонерних товариств. Корпоративне підприємство утворюється, як правило, двома або більше засновниками за їх спільним рішенням (договором), діє на основі об'єднання майна та/або підприємницької чи трудової діяльності засновників (учасників), їх спільного управління справами, на основі корпоративних прав, у тому числі через органи, що ними створюються, участі засновників (учасників) у розподілі доходів і ризиків підприємства [1]. Ця форма господарювання в умовах економічної нестабільності має певні переваги:

1) мінімізує фінансовий ризик діяльності акціонерів внаслідок виключення за чинним законодавством їхньої відповідальності перед кредиторами товариства за межами капіталу, що розміщений в акціях;

2) сприяє збільшенню концентрації виробництва, підвищенню рівня капіталізації, вигідному інвестуванню та інноваційному розвитку;

3) дозволяє здійснювати підприємницьку діяльність, розширювати та диверсифікувати їі навіть після зміни складу акціонерів;
4) можливість участі працівників у розподілі прибутків, що дає змогу власникам корпорацій успішно реалізовувати стратегічні плани на засадах колективних інтересів, корпоративної соціальної відповідальності тощо [2, с. 123].

Водночас, попри можливості мінімізації ризиків, корпоративні підприємства все ж діють в умовах динамічних змін та невизначеності середовища, що призводить до виникнення ризикових ситуацій, що характеризуються [3]: випадковим характером події, невизначеністю можливості досягнення суб'єктом господарських цілей; наявністю декількох варіантів розвитку події чи стану середовища, включаючи негативні, пов'язані з виникненням збитку, упущеної вигоди, недосягнення суб'єктом своїх цілей; можливістю прогнозування ймовірності очікуваних результатів; можливістю розуміння суб'єктом господарювання об'єктивних невизначеностей, урахування ймовірного негативного та позитивного впливу в процесі прийняття рішень щодо діяльності підприємства, націлених на забезпечення його фінансової стабільності та стійкості [4].

За таких умов, першочерговим є впровадження ризик-орієнтованого менеджменту - управління підприємством загалом з урахуванням впливу ризиків на основі процесу їх ідентифікації, оцінювання та аналізування, а також вибору та використання методів нейтралізації їх наслідків задля досягнення оптимального співвідношення рівня ризику та стратегічних можливостей підприємства [5, с. 33]. 
Таблиця 1. Основні ризики діяльності корпоративних підприємств

\begin{tabular}{|c|c|}
\hline Ризики & Характеристика \\
\hline \multicolumn{2}{|r|}{ Зовнішні } \\
\hline Політичні & $\begin{array}{l}\text { Спричинені війнами, революціями, демократичні зміни в уряді, інші } \\
\text { політичні }\end{array}$ \\
\hline Законодавчі & $\begin{array}{l}\text { Недостатність законодавчого забезпечення, часта зміна, протиріччя у } \\
\text { законодавчих актах, що регулюють діяльність підприємства, вплив } \\
\text { реформ }\end{array}$ \\
\hline Соціальні & $\begin{array}{l}\text { Залежать від соціального стану населення, суспільного незадоволення } \\
\text { тощо }\end{array}$ \\
\hline Макроекономічні & $\begin{array}{l}\text { Вплив інфляції, зміни у відносних цінах, валютних курсах, відсоткових } \\
\text { ставок, умов торгівлі }\end{array}$ \\
\hline Природні & Ймовірність стихійних лих, природних катастроф, зміни клімату \\
\hline \multicolumn{2}{|r|}{ Внутрішні } \\
\hline $\begin{array}{l}\text { Виробничо- } \\
\text { операційні }\end{array}$ & $\begin{array}{l}\text { Ризики засобів виробництва, нестача сировини, зміна якості продукції, } \\
\text { трудові конфлікти та зниження продуктивності праці, технологічні } \\
\text { обмеження виробництва, випадкові виробничі негаразди }\end{array}$ \\
\hline Інвестиційні & $\begin{array}{l}\text { Пов'язані з інвестуванням проектів, що можуть не принести інвесторам } \\
\text { іх очікувані прибутки }\end{array}$ \\
\hline Ринкові & $\begin{array}{l}\text { Пов’язані зі зміною кон’юнктури ринку, зміни споживчих уподобань, } \\
\text { наявності товарів-замінників, дефіцит комплементарних товарів, } \\
\text { нерівномірність технологічності та інноваційної продукції, нові } \\
\text { учасники ринку тощо }\end{array}$ \\
\hline Підприємницькі & $\begin{array}{l}\text { Пов'язані з розширенням масштабів виробництва, неповним } \\
\text { використанням виробничих потужностей, непередбаченими витратами } \\
\text { й втратами, зменшенням прибутку та банкрутством }\end{array}$ \\
\hline $\begin{array}{l}\text { Фінансово- } \\
\text { комерційні }\end{array}$ & $\begin{array}{l}\text { Ризики непередбачених штрафів, втрат при здійсненні валютних } \\
\text { операцій і операцій з цінними паперами, невиконання партнерами умов } \\
\text { контракту }\end{array}$ \\
\hline Науково-технічні & $\begin{array}{l}\text { Ризики не впровадження інноваційних технологій та нових методів } \\
\text { виробництва, інновацій в управлінні, неточні результати науково- } \\
\text { практичних досліджень }\end{array}$ \\
\hline Професійні & $\begin{array}{l}\text { Пов’язані із низьким кваліфікаційним рівнем управлінського персоналу } \\
\text { підприємства, який складає недостатньо обгрунтовані виробничі та } \\
\text { фінансові плани }\end{array}$ \\
\hline $\begin{array}{l}\text { Корпоративного } \\
\text { управління }\end{array}$ & $\begin{array}{l}\text { Ризики зміни корпоративної структури компанії, реорганізації, } \\
\text { банкрутства, недобросовісності акціонерів, незацікавленості } \\
\text { керівництва справами підприємства тощо }\end{array}$ \\
\hline
\end{tabular}

Ажерело: доповнено авторами за [9; 10].

В Україні основою для ризик-орієнтовного менеджменту підприємств, незалежно від організаційної форми, є міжнародний стандарт ISO 31000:2018 [6], який встановлює принципи, структуру та процес управління ризиками та має допомогти регулювати фактори невизначеності функціонування суб'єктів господарювання. В Україні застосовують аналог Аержавного стандарту ACTУ ISO 31000:2018 "Менеджмент ризиків. Принципи та настанови" [7] введений в дію з 1 січня 2019 року. Стандарт визначає концепцію загального оцінювання та управління ризику, яка повноцінно може застосовуватися у менеджменті корпоративних підприємств і передбачає такі кроки:

— аналіз оточення - збір інформації та обробка даних про структуру та властивості об'єкту, визначення стратегічних й тактичних цілей підприємницької діяльності в умовах ризику, аналіз стану та перспектив розвитку внутрішнього та зовнішнього середовища.

- ідентифікація ризику - моніторинг змін, що відбуваються у зовнішньому та внутрішньому середовищі організації, переходячи до розкриття всіх елементів ризиків; оцінка ймовірності настання ризикових подій, визначення площин підвищеного ризику, визначення ступеня впливу ризику, рівня небезпеки та можливі наслідки і розміри збитку та документація їх характеристик.

- аналіз ризику - одержання необхідної інформації щодо структури та властивостей об'єкту ризику, виявлення основних видів ризику, що впливають на цей об'єкт та його оцінювання: розуміння кожного ризику, його наслідків та ймовірностей цих наслідків (допустимий для підприємства рівень ризику).

- оптимізація ризиків - розробка механізмів управління ризиками (планування та фінансування заходів з управління ризиками, оцінка ефективності системи управління ризиками, моніторинг динаміки зміни ризиків, звітність 3 управління ризиками, періодичне навчання персоналу ризик-менеджменту тощо), складання стратегічного плану заходів, спрямованих на зниження економічних втрат і пом'якшення дії факторів ризику, розробка методів та технологій нейтралізації впливу ризику, прийняття ризику, передача частини або всього ризику третім особам [8].

За реалізацію оцінювання та управління ризиками підприємства відповідає система ризик-орієнтовного менеджменту, яка включає в себе суб'єкта, об'єкт, методи, способи, інструменти управління та грунтується на окремих принципах ефективного менеджменту. Проте, на наш погляд, варто зважати, що система ризик-орієнтовного менеджменту корпоративних підприємств (рис. 1) у сучасних умовах має певні особливості.

Насамперед, розглядаючи об'єкт системи ризикорієнтованого менеджменту - зовнішні та внутрішні Ажерела та чинники ризику, що негативно впливають на діяльність підприємства, а також виявлені небезпеки і загрози, яким піддається корпоративне підприємство (табл. 1) у ході своєї діяльності, стає очевидним, що воно вразливе до певних ризиків корпоративного управління, зокрема:

- рівень ризику "розмивання" частки акціонерів у статутному капіталі;

- ризик конфлікту інтересів;

- ступінь обгрунтованості введення трансфертного ціноутворення;

- ступінь імовірності банкрутства;

- рівень ризику від реорганізації підприємства та виходу акціонерів із складу стейкхолдерів; 
- рівень ризику від зміни корпоративної структури компанії (незавершеність консолідації холдингів);

- рівень ризику від відсутності представників міноритарних акціонерів у складі ради директорів;

- рівень ризику, пов'язаний з участю в акціонерних товариствах держави як акціонера.

Щодо визначення суб'єктів системи ризик-орієнтовного менеджменту корпоративних підприємств у сучасних умовах, вважаємо за доцільне впроваджувати систему управління ризиками в межах усього підприємства, за якої управлінням ризиком займаються не тільки фахівці з ризик-менеджменту, а й акціонери, безпосередні керівники підприємства та його структурних підрозділів, всі працівники кожного функціонального відділу підприємства. Такий комплексний підхід дозволить встановити зацікавленість кожної ланки корпоративного підприємства та відповідальність за протидію всім видам ризику, що загрожують його діяльності. Якк наслідок, можна оптимізувати стратегію компанії, бізнес-процеси, управління людськими ресурсами, а також виробничо-операційними й технологічними процесами.

Серед методів системи ризик-менеджменту виділяються загальні (до яких належать економічні, організаційні, соціально-психологічні) та спеціальні (які використовуються для виконання окремих функцій ризикменеджменту), а способами управління ризиками визначаються: уникнення (виключення, відмова від високоризикових бізнес-процесів); скорочення (оптимізація, мінімізація, зниження ризиків); обмін (передача ризиків третім особам, страхування); утримання (прийняття і створення резервного плану дій в разі настання ризикового випадку).

Як інструменти системи ризик-орієнтовного менеАжменту корпоративних підприємств можна застосовувати:

1. Страхування - захист майнових інтересів підприємства або окремих його структурних підрозділів при настанні страхової події спеціальними страховими компаніями. Найчастіше страхування здійснюється від ринкових, підприємницьких, природних, законодавчих і політичних ризиків. У випадку страхування підприємство повинно вносити страхові внески, тобто згодне передати частину доходів задля уникнення ризику. Крім того, можливе внутрішнє страхування, коли страхування ризиків здійснюється в рамках самого підприємства шляхом створення децентралізованих резервних і страхових фондів з відшкодування збитків та/або визначених запасів за рахунок прибутків чи власних оборотних коштів. Такий інструмент ризик-менеджменту виправданий у випадках, коли витрати на резервування засобів менше, ніж вартість страхових внесків при страхуванні.

2. Хеджування - специфічна форма страхування ризиків від несприятливих змін цін на будь-які товарноматеріальні цінності по контрактах і комерційних операціях, що передбачають постачання (продаж) товарів в майбутніх періодах. Аає змогу виключити або обмежити ризики фінансових операцій через несприятливі зміни курсу валют, цін на товари, послуги, відсоткових ставок тощо в майбутньому.

3. Аімітування - передбачає обмеження верхніх і нижніх порогів грошових, товарних, кредитних, інвестиційних витрат на величину можливого збитку, тим самим знижуючи ступінь ризику. Цей інструмент використовують для зменшення ризику в кредитній та інвестиційній діяльності суб'єкта господарювання: під час продажу товарів у кредит, наданні позичок, при прийнятті рішень щодо визначення обсягу коштів, що спрямовуються на інвестування.

4) диверсифікація - застосовується для зменшення ризику за рахунок його розподілу між різними об'єктами вкладення, які безпосередньо не пов'язані між собою складовими, що характеризуються певним рівнем ризику. Здійснюється шляхом збільшення числа інвес- торів, постачальників і споживачів, розширення видів діяльності тощо, адже якщо в результаті непередбаченИх Подій ОдИн вид діяльності буде збитковим, інший приноситиме прибуток.

5. Забезпечення якості виготовленої продукції при одночасній мінімізація витрат на її виготовлення. Важливим шляхом забезпечення якості процесів виробництва $є$ підвищення керованості технологічними процесами виготовлення продукції, покращення операційного управління, покращення професійності працівників та якості їхньої роботи.

6. Розподіл ризику - перенесення частки відповідальності за ризик на співучасника інвестиційного проекту, здатного контролювати його краще від інших. Здійснюється передача всього ризику або його частини замовникові, субпідрядникові або третій стороні: страхування об'єкта і, відповідно, передача ризику страховій компанії; включення відповідальності за ризик у контракт із підрядником; фіксування ціни контракту, ціноутворення у твердій валюті і т.п.

7. Бізнес-планування - передбачає пошук подальших резервів зменшення витрат і зростання доходів підприємства. Особлива увага приділяється не тільки визначенню очікуваного обсягу прибутку від реалізації бізнес-ідеї, а й вивченню умов на ринку даних послуг, виявленню можливостей розширення обсягів їх реалізації у майбутньому, можливих джерел фінансування проекту з урахуванням умов отримання кредиту та строків його погашення. Ефективне планування з необхідними розрахунками, обгрунтуваннями дозволяє зрозуміти перспективи своєї справи, передбачити можливі коливання та проблеми в майбутньому й пристосуватися до змін кон'юнктури ринку, контролювати поточні операції, знизивши в такий спосіб рівень ризику [11;12].

Зважаючи на те, що для кожного корпоративного підприємства залежно від видів діяльності, фінансової стійкості, участі акціонерів в управлінні, ринкової кон'юнктури та інших внутрішніх й зовнішніх чинників, ризик $є$ індивідуальним, тому і використання інструментів управління ним має передбачати індивідуальний підхід. Тому залежно від аналізу середовища та ідентифікації ризиків обирається оптимальний інструмент або іх комбінації, яка дозволить максимально ефективно мінімізувати втрати від настання несприятливих бізнес-обставин.

Щодо принципів системи ризик-орієнтовного менеджменту, вважаємо, що вони є загальнішими та повинні базуватися на засадах ISO 31000: 2018 [6] та включати: структурованість та всеосяжність менеджменту; інтегрованість в загальну систему управління; системність; економічна обгрунтованість; адаптованість до зовнішнього та внутрішнього середовища організації; динамічність; актуальність та оперативність; постійного моніторингу та удосконалення.

Таким чином, ризик-орієнтовний менеджмент у корпоративних підприємствах є вимогою сучасних умов господарювання та, як нова тенденція в сучасному управлінні, здатний створити можливості для контролю та уникнення (зменшення впливу) ризиків, які в майбутньому можуть позначитися на діловій репутації [13] та загальній економічній ефективності діяльності, за рахунок формування та функціонування повноцінної системи ризик-менедженту підприємства.

\section{ВИСНОВКИ І ПЕРСПЕКТИВИ ПОДАЛЬШИХ ДОСЛІДЖЕНЬ}

Головною запорукою ефективної діяльності корпоративного суб'єкта господарювання в існуючому нині невизначеному середовищі має стати формування системи ризик-орієнтовного менеджменту на підприємстві, яка передбачає управління ризиками на основі процесу ї ідентифікації, оцінки та аналізу, а також вибору і використання методів нейтралізації їх наслідків з метою 
забезпечення стабільності та конкурентоспроможності підприємства, повинна стати невід'ємною складовою частиною менеджменту та стратегічного планування корпоративного підприємства, об'єднуючи всі його функціональні підрозділи у контролі та управлінні ризиками, що досягається визначеними способами, інструментами та принципами.

Тому загалом можемо дійти висновку, що проведене дослідження має теоретичну та практичну цінність. Теоретична цінність полягає у розширенні наукових поглядів щодо системи ризик-орієнтовного менеджменту корпоративних підприємства, ураховуючи специфічні ризики їх діяльності. Практична цінність полягає у формулюванні рекомендацій щодо формування такої системи ризик-орієнтовного менеджменту корпоративних підприємств та її структурних елементів.

Подальші дослідження варто спрямувати на розроблення методичних підходів до оцінки ефективності системи ризик-орієнтовного менеджменту корпоративного підприємства.

\section{$\Lambda$ ітература:}

1. Господарський Кодекс України. URL: https:// zakon.rada.gov.ua/laws/show/436-15\#Text

2. Антоненко B.I. Корпоративне управління - важливий елемент менеджменту на підприємстві. Вісник КНТЕУ. 2014. № 3. С. 120-128.

3. Коломієць Г.І. Податкові ризики: сутність та класифікація. Ринок цінних паперів. 2009. № 6. С. 27-33.

4. Ковернега Т.А. Особливості формування стратегії управління економічними ризиками для забезпечення економічної безпеки на вітчизняних підприємствах. Науковий вісник ХАУ. Серія "Економічні науки". Вип. 8. Ч. 7. Херсон, 2014. С. 98-102.

5. Балдин К. Риск-менеджмент: учеб. пособие. Москва: Эксмо, 2006. 368 с.

6. ISO 31000:2018 Riskmanagement - Guidelines. URL: https://www.iso.org/obp/ui/\#iso:std:iso:31000:ed-2:v1:en

7. Метрологія, 2014. АСТУ IEC/ISO 31010:2013. Національний стандарт України. Керування ризиком. Методи загального оцінювання ризику. URL: http:// metrology.com.ua/download/iso-iecohsas-i-dr/87-eea/ 1062-dstu-ies-iso-31010-2013.

8. Аячков А.В. Формування системи ризик-менеджменту підприємства. Економічний форум. 2015. № 4. C. $235-241$.

9. Аовганець О., Аовба I. Роль ризик-менеджменту в системі корпоративного управління. Геополітика України: історія і сучасність. Вип. 2 (23), 2019. С. 147-163.

10. Берегова Т.А. Ризик-менеджмент як важливий інструмент забезпечення економічної безпеки на вітчизняних харчових підприємствах. Молодий вчений. 2015. № 11 (2). C. $14-18$.

11. Волинець I. Організація ризик-менеджменту на підприємстві. Економічний часопис Східноєвропейського національного університету імені Аесі Українки. 2016. № 2. C. $51-55$.

12. Корж Н.В. Методи управління фінансовими ризиками. Траектория науки. 2016. № 10. С. 1.1-1.6.

13. Кривець Ю.М. Підвищення ефективності корпоративного управління агроформувань на засадах визначення принципів, рейтингових оцінок індикаторів, ризик-менеджменту та контролінгу. Наукові праці Полтавської державної аграрної академії. Економічні науки. 2015. Вип. 1 (10). С. 170-175.

References:

1. The Verkhovna Rada of Ukraine (2003), "The Commercial Code of Ukraine", [Online], available at: https:/ /zakon.rada.gov.ua/laws/show/436-15\#Text (accessed: 25.01.2021).

2. Antonenko, V. I. (2014), "Corporate governance is an important element of management at the enterprise",
Visnyk KNTEU, vol. 3, pp. 120-128.

3. Kolomiyets', H.I. (2009), "Tax risks: nature and classification", Rynok tsinnykh paperiv, vol. 6 , pp. $27-33$.

4. Koverneha, T. A. (2014), "Features of formation of strategy of management of economic risks for maintenance of economic safety at the domestic enterprises", Naukovyy visnyk KHDU. Seriya "Ekonomichni nauky", vol. 8 (7), pp. $98-102$.

5. Baldin, K. (2006), Risk-menedzhment [Risk management], Exmo, Moscow, Russia.

6. ISO (2018), "ISO 31000:2018 Risk management Guidelines", [Online], available at: https://www.iso.org/ obp/ui/\#iso:std:iso:31000:ed-2:v1:en (accessed: 03.02.2021).

7. Ministry of Economic Development and Trade of Ukraine (2014), "DSTU IEC / ISO 31010: 2013. National standard of Ukraine. Risk management. Methods of general risk assessment", [Online], available at: http://metrology.com.ua/download/iso-iec-ohsas-i-dr/87-eea/1062dstu-ies-iso-31010-2013 (accessed: 03.02.2021).

8. Dyachkov, D. V. (2015), "Formation of enterprise risk management", Ekonomichniy forum, vol. 4. pp. 235-241.

9. Dovhanets', O. and Dovba, I. (2019), "The role of risk management in the corporate governance system", Heopolityka Ukrayiny: istoriya i suchasnist', vol. 2 (23), pp. 147-163.

10. Berehova, T. A. (2015), "Risk management as an important tool for ensuring economic security in domestic food enterprises", Molodyy vchenyy, vol. 11 (2), pp. 14-18.

11. Volinets, I. (2016), "The Organization of Risk Management at the Enterprise", Ekonomichniy chasopis Shidnoevropeyskogo natsionalnogo universitetu imeni Lesi Ukrayinki, vol. 2, pp. $51-55$.

12. Korzh, N. V. (2016), "Methods of Financial Risk Management"]. Traektoriya nauki, vol. 10, pp 1.1-1.6.

13. Kryvets', Yu. M. (2015), "Improving the efficiency of corporate governance of agricultural formations on the basis of determining the principles, rating assessments of indicators, risk management and controlling", Naukovi pratsi Poltavs'koyi derzhavnoyi ahrarnoyi akademiyi. Ekonomichni nauky, vol. 1 (10), pp. 170-175.

Стаття надіймла до редакиії 09.03.2021 р. www. dy.nayka.com.ua

Електронне фахове видання

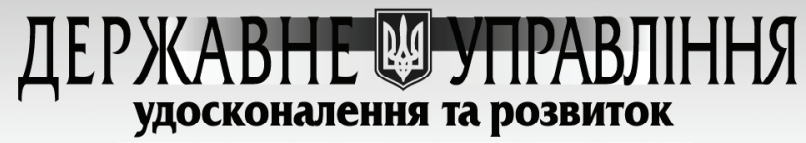

Виходить 12 разів на рік

включено до переліку наукових фахових видань України 3 Питань ДЕРЖАВНОГО УПРАВЛПННЯ

(Категорія «Б»)

Наказ Міністерства освіти і науки України від 28.12.2019 №1643

Спеціальність 281

e-mail: economy_2008@ukr.net

тел.: (044) 223-26-28, (044) 458-10-73 